FOLIA POMERANAE UNIVERSITATIS TECHNOLOGIAE STETINENSIS

Folia Pomer. Univ. Technol. Stetin., Oeconomica 2018, 342(90)1, 47-58

Irena $Ł A ̨ C K A$

\title{
MODELE Quadruple i Quintuple Helix - NOWE SPOJRZENIE NA ROLĘ SPOKECZEŃSTWA I ŚRODOWISKA NATURALNEGO W TWORZENIU REGIONALNYCH INNOWACJI DLA ROZWOJU ZRÓWNOWAŻONEGO
}

\section{Quadruple and Quintuple Helix MODELS - A NEW PERSPECTIVE ON A ROLE OF SOCIETY AND NATURAL ENVIRONMENT IN THE CREATION OF REGIONAL INNOVATIONS FOR SUSTAINABLE DEVELOPMENT}

Katedra Ekonomii i Rachunkowości, Zachodniopomorski Uniwersytet Technologiczny w Szczecinie, ul. Żołnierska 47, 71-210 Szczecin

\begin{abstract}
Summary. The creation of regional innovations in a knowledge-based economy demands the cooperation of different partners - research and academic institutions, companies, local authorities, non-governmental organisations, society and media. In recent years, relations between them became more and more crucial in the context of creating and introducing innovations for sustainable development on a microcosm, mesocosm and macrocosm scale. Theoretical frameworks of this cooperation formulate models of the quadruple and quintuple helix. They constitute an advancement of Etzkowitz and Leyesdorff concept of a triple helix (university-industry-government) to media and society (quadruple helix). Then, they extended the idea by an ecological context - a nation of XXI century which lives in a natural environment and has to consider the rules of a sustainable development (quintuple helix). The aim of the study is to present the indicated concepts and meaning of civil society and the natural environment in these models of cooperation. The analysis of foreign and national literature on the subject was used in the work. A theoretical elaboration signals an urge for new perspectives by regional stakeholders on the mechanism and the conduct of innovative processes aimed at creating solutions to contemporary problems of the worldwide economy. Quadruple and Quintuple Helix concepts in Poland are not yet widely known or implemented. It is necessary to influence the scientific community on the creation of such cooperation networks in the region in order to create innovations in the conditions of sustainable development.
\end{abstract}

Słowa kluczowe: quadruple helix, quintuple helix, społeczeństwo, rozwój zrównoważony, innowacje, region, środowisko naturalne.

Key words: quadruple, quintuple helix, society, sustainable development, innovations, region, natural environment.

\section{WSTĘP}

Społeczeństwa różnych krajów bardziej i mniej rozwiniętych (w tym Polski) stoją przed wieloma obecnymi i przyszłymi wyzwaniami rozwojowymi. Wśród nich są te, które determinują zrównoważony rozwój w makro-, mezo- i mikroskali. Występują one we wszystkich obszarach otoczenia społeczeństwa, tzn. w obszarze ekonomicznym, społeczno-demograficznym, technologicznym, ekologicznym, politycznym i prawnym. Długookresowy rozwój społeczno-gospodarczy kraju i regionu, a także ich konkurencyjność warunkowane są (Dolińska 2010; Carayannis i in. 2012; Mitek i Miciuła 2012; Barca i in. 2012; Camagni i Capello 2013; Spark. Scale. Sustain... 2017; Harari 2018; Nowicki 2018): 
- zdolnością podmiotów gospodarczych do tworzenia i wdrażania nowych rozwiązań (innowacji) w warunkach gospodarki opartej na wiedzy, coraz szybszego postępu technicznego;

- koniecznością dostosowywania się przedsiębiorstw i innych interesariuszy (w skali regionu i kraju) do burzliwego otoczenia, nasilonej konkurencji, niepewnej przyszłości, globalizacji, megatrendów, ograniczeń rozwojowych ludzkości związanych z kurczącymi się zasobami naturalnymi, z globalnym ociepleniem, polaryzacją dochodową, problemami głodu w niektórych częściach świata, właściwymi relacjami między człowiekiem a technologią;

- odpowiedzialnością człowieka za stworzenie warunków do długookresowego wzrostu dobrobytu społecznego i jednostkowego oraz za harmonijne relacje między człowiekiem a przyrodą (osiągnięcie rozwoju zrównoważonego, który zapewni zaspokojenie potrzeb obecnych pokoleń, przy zachowaniu możliwości realizacji potrzeb i pragnień pokoleń późniejszych);

- umiejętnością wykorzystywania znajdujących się w lokalnym i regionalnym otoczeniu zasobów innowacyjnych należących do różnych partnerów w ramach regionalnych systemów innowacyjnych (RSI);

- zdolnością do tworzenia sieci współpracy na potrzeby procesów innowacyjnych i osiągania efektów synergicznych między partnerami sieci (przedsiębiorstw, uczelni, instytucji badawczo-rozwojowych, władz lokalnych, samorządowych, instytucji wspierających innowacje i transfer technologii oraz innych podmiotów);

- prowadzoną polityką innowacyjną sprzyjającą aktywności innowacyjnej podmiotów gospodarczych, skłaniającą je do podejmowania przedsięwzięć innowacyjnych, prowadzenia prac badawczo-rozwojowych, zakupu gotowej wiedzy, podnoszenia jakości kapitału ludzkiego;

- wspieraniem przez politykę innowacyjną nawiązywania relacji między światem nauki a światem gospodarki, transferu wiedzy i komercjalizacji technologii;

- wzmacnianiem postaw innowacyjnych w społeczeństwie za pomocą różnych narzędzi polityki państwa.

Współcześnie ideę i zasady współpracy między regionalnymi aktorami procesów innowacyjnych w sytuacji wskazanych wyzwań gospodarki światowej i oczekiwań społeczeństwa wyjaśniają trzy modele: potrójnej, poczwórnej i pięciokrotnej helisy (Triple Helix, Quadruple Helix i Quintuple Helix). Celem naukowym opracowania jest zaprezentowanie dwóch ostatnich modeli oraz ustalenie roli społeczeństwa obywatelskiego i środowiska naturalnego w procesie tworzenia i wdrażania innowacji w regionie we współpracy opartej na modelach poczwórnej i pięciokrotnej helisy, w warunkach zrównoważonego rozwoju. Przygotowując opracowanie, korzystano z analizy zagranicznej i krajowej literatury przedmiotu. Zawarte w artykule wnioski z badań nad literaturą przedmiotu wskazują potrzebę innego podejścia uczestników RSI do tworzenia i wdrażania innowacji w polskich regionach. Powinno ono uwzględniać, z jednej strony, nowe wyzwania gospodarki światowej, a z drugiej strony nowe możliwości tkwiące w dwóch ważnych obszarach sieci współpracy, tzn. w podsystemie społeczno-kulturowym (tworzącym społeczeństwo obywatelskie) oraz w podsystemie środowiska naturalnego, w którym żyje społeczeństwo. 


\section{OD KONCEPCJI REGIONALEGO SYSTEMU INNOWACJI DO MODELU POTRÓJNEJ HELISY}

Koncepcja regionalnego systemu innowacji (RIS) pojawiła się w rozważaniach nad warunkami rozwoju regionalnego i konkurencyjności regionalnej za sprawą Braczyka, Cooke i Heidenreicha w 1988 r. (Braczyk i in. 1988). W 1995 r. została wykorzystana przez Etzkowitza i Leyesdorffa do stworzenia systemu (modelu) potrójnej helisy, pozwalającego zrozumieć dynamiczne interakcje zachodzące między uczelniami, instytucjami otoczenia biznesu, przedsiębiorstwami i instytucjami władzy, które sprzyjały przedsiębiorczości, innowacjom i wzrostowi gospodarczemu. Od tej pory koncepcja RSI ewoluuje (Cooke i in. 1992; Doloreux i Parto 2005), ale nadal wskazuje się, że podstawą tworzenia i wdrażania innowacji jest region. Jego podmioty organizują się wokół regionalnego systemu innowacji, czyli sieci współpracy między organizacjami i instytucjami działającymi w regionie, wspierającymi potencjał innowacyjny przedsiębiorstw. Według Staniendy (2011) regionalny system innowacji to „[...] elastyczny, kreatywny i regionalny socjoekonomiczny układ o jak najszerszych powiązaniach, który wykorzystuje lokalne atrybuty i zasoby decydujące o produkcji i produkcie w odpowiedni sposób do specyfiki lokalnego rynku" (s. 157). Wyróżnia się kilka podsystemów obejmujących różne grupy podmiotów regionalnych uczestniczących w procesach innowacyjnych. Należą do nich podsystemy (Markowski 2000):

- produkcyjno-usługowy - tworzą go przedsiębiorstwa, zgłaszające popyt na innowacje;

- naukowo-badawczy - obejmuje uczelnie, instytuty naukowo-badawcze, oferujące wiedzę, wyniki prac badawczych, gotowe nowe rozwiązania, prawa własności do wynalazków, know-how, uczestniczące w kształceniu kadr dla gospodarki;

- instytucjonalny - ośrodki wspierania innowacji, transferu wiedzy i technologii, ich komercjalizacji, dyfuzji innowacji (centra transferu technologii, parki naukowo-technologiczne, inkubatory technologiczne), ośrodki wspierające przedsiębiorczość, firmy konsultingowe, klastry, instytucje finansowe, w tym kapitału wysokiego ryzyka. Podmioty te mają za zadanie wspierać procesy innowacyjne. W tym podsystemie znajdują się także lokalne i regionalne władze wraz ze stosowaną polityką gospodarczą, w tym innowacyjną;

- społeczno-kulturowy - tworzony przez wyjątkowe i charakterystyczne dla regionu cechy kulturowe (tradycję, historię), systemy wartości, formy i kanały komunikacji, kapitał społeczny i poziom zaufania niezbędny do nawiązywania współpracy w wielu sferach.

W gospodarce opartej na wiedzy realizacja przedsięwzięć innowacyjnych w wymiarze regionalnym wymaga współpracy sieciowej między uczestnikami wymienionych podsystemów. Według teorii, popartej wieloma dowodami empirycznymi sukcesów współpracy między uczestnikami procesów innowacyjnych w regionach wielu krajów, sieć umożliwia:

- osiąganie większych efektów w wyniku synergii;

- łatwiejszy dostęp do zasobów, w tym wiedzy, informacji, nowych rozwiązań;

- szybsze komunikowanie się partnerów w procesach innowacyjnych i prorozwojowych;

- dzielenie się kosztami tworzenia i wdrażania innowacji oraz ryzykiem towarzyszącym działalności innowacyjnej;

- uzyskiwanie korzyści w postaci współtworzenia nowych rozwiązań najbardziej odpowiadających zapotrzebowaniu;

- racjonalne gospodarowanie zasobami rzeczowymi i ludzkimi; 
- szybsze wprowadzanie innowacji,

- poprawę innowacyjności i konkurencyjność współpracujących w RIS podmiotów.

Początkowo za najważniejsze elementy tego systemu uznawano uniwersytety, finansowe i pozafinansowe organizacje wsparcia przedsiębiorczości i innowacji, transferu technologii, a także przemysł i administrację (tzw. triada university-industry-government). To posłużyło Etzkowitzowi i Leyesdorffowi do stworzenia w 1995 r. modelu ich współpracy, zależności i interakcji (Etzkowitz i Leyesdorff 1995), znanego pod nazwą potrójnej helisy (the Triple Helix). W gospodarce opartej na wiedzy optymalne warunki do zwiększenia konkurencyjności gospodarki oraz wzrostu i rozwoju przedsiębiorstw zapewniają: siła i rodzaje relacji związanych z przepływem wiedzy, jej wykorzystaniem do tworzenia nowych rozwiązań, a potem ich wdrażania na rynku. W takich warunkach społeczeństwo poddawane jest ciągłej transformacji, którą wymuszają zmiany w technosferze, ale także w pozostałych obszarach otoczenia.

We współczesnej gospodarce kontakty między uczestnikami procesów produkcji, podziału, wymiany i konsumpcji w regionie zmieniły się $z$ linearnych, powstających jako reakcja na działania poszczególnych interesariuszy (market pull lub technology push), na działania relacyjne, z aktywnym udziałem poszczególnych partnerów w różnych etapach tworzenia, podziału, wymiany oraz konsumpcji wiedzy i innowacji. Zmianie uległy klasyczne podziały na dostawców i odbiorców wiedzy, nowych rozwiązań, zasobów niezbędnych do działalności innowacyjnej (Leysdorff 2012). Zależności między partnerami tej współpracy nie są określone z góry i podlegają ciągłym przemianom. Procesu tworzenia innowacji w „nowej” gospodarce nie determinują jedynie możliwości i zdolności innowacyjne pojedynczych organizacji - w znacznym stopniu jest to wynik sieciowo zorganizowanego systemu kooperacji, interakcji między trzema helisami. Model potrójnej helisy pokazuje, jak grupy interesariuszy tworzą zachodzące na siebie sfery - kręgi. W wyniku wzajemnego oddziaływania zmieniają one swoje role, możliwości w procesach tworzenia i transformacji wiedzy na potrzeby nowych idei, pomysłów, rozwiązań (produktowych, usługowych, procesowych, organizacyjnych lub marketingowych). Ich relacje przyjmują zarówno charakter dwustronny (uznawany za negatywny sposób konfiguracji trzech podsystemów), jak i wielostronny - polegający na interakcjach partnerów między sobą (struktura potrójnej helisy). To dodatkowo doprowadza do powstawania organizacji hybrydowych, np. firm spin-ff, start-up, klastrów przemysłowych, parków technologicznych, nowych przedsiębiorstw będących wynikiem aliansów strategicznych, laboratoriów badawczych publiczno-prywatnych (pozytywna konfiguracja podsystemów).

W takiej strukturze każdy z trzech kręgów odgrywa równorzędną rolę. Uniwersytety realizują w regionie wszystkie funkcje: badawcze, edukacyjne i przedsiębiorcze (za pośrednictwem firm spin-off, sprzedaży prac do wynalazków, patentów) w duchu nowocześnie postrzeganego uniwersytetu trzeciej generacji, a poza tym angażują się w życie regionalne jako animatorzy koncepcji rozwojowych, organizatorzy życia społeczno-gospodarczego, lobbyści rozwoju regionalnego. Uniwersytety postrzegane są również jako „[...] intelektualne sumienie społeczeństwa, czyli niezależne instytucje wypowiadające się w sposób bezstronny w ważnych dla państwa sprawach [...]" (Sojusz głów 2018, s. 67). Podobne zmiany ról i funkcji są dostrzegane w przypadku pozostałych partnerów potrójnej helisy. Poza swymi naturalnymi zadaniami (produkcyjnymi dla przedsiębiorstw i regulacyjnymi dla administracji) podmioty te 
podejmują inne role. Przedsiębiorstwa i ich przedstawiciele mogą realizować działalność edukacyjną, kształcąc kadry (szkolenia dla pracowników, staże dla studentów i uczniów, prowadzenie wykładów na uczelniach) oraz podejmując działalność naukowo-badawczą (prace $B+R$, badania stosowane i prace rozwojowe we własnych laboratoriach i centrach badawczych). Podmioty administracji publicznej i samorządowej mogą wykształcić umiejętności biznesowe poprzez finansowe i prawne wspieranie przedsiębiorczości w regionie (Bojar i Machnik-Słomka 2014).

\section{SPOKECZEŃSTWO I MEDIA JAKO ELEMENTY MODELU POCZWÓRNEJ HELISY}

W XXI w. koncepcja tworzenia wiedzy w regionalnych systemach innowacji podlegała dalszej ewolucji - model potrójnej helisy rozszerzono o jeszcze jedną sferę uczestników społeczeństwo obywatelskie oparte na wiedzy i demokracji. Jego autorami są Carayannis i Campbell (2009), którzy przyjęli, że procesy innowacyjne w regionie oparte są na powiązaniach nauki, biznesu i władzy (systemu politycznego). Jednocześnie są też inspirowane i współrealizowane przez społeczeństwo oraz media i organizacje non-profit (np. instytucje kultury, organizacje konsumenckie). Media prezentują opinie, postawy i wartości członków społeczeństwa, którzy często także integrują się wokół wspólnych celów w ramach organizacji III sektora (Carayannis i Campbell 2009). Model ten opisuje nowe środowisko gospodarcze, w którym cale społeczeństwo zaangażowane jest w kreowanie wiedzy i innowacji na potrzeby wzrostu gospodarczego i rozwoju regionu (Afonso et al. 2010).

Podkreśla się także znaczenie społeczeństwa obywatelskiego (użytkowników nowych rozwiązań) we współtworzeniu innowacji. Wynika to z konieczności dobrego zrozumienia potrzeb nabywców i uwzględnienia ich w procesie tworzenia nowych rozwiązań. W celu ułatwienia rozpoznania tych potrzeb nabywcy są włączani w proces innowacyjny, a ich wiedza i umiejętności są wykorzystywane do rozwijania nowych produktów i usług, odpowiadających nowym potrzebom, zmieniającym się gustom konsumentów lub stylów życia (koncepcje open innovation lub user driven innovation). Przykładem tego rodzaju postępowania jest rozwój internetu i telefonii komórkowej, które mają charakter generatywnych platform innowacyjnych. Poza niezbędnymi dla ich rozwoju innowacjami przełomowymi pełne wykorzystanie i rozwój tych mediów zależy od aktywności użytkowników. W tym wypadku istotne są nie tylko ich opinie na temat oferty (ujawniane w badaniach marketingowych) oraz kompetencje techniczne, ale także zdolności kreatywne. Odbiorcy końcowi proponowanej oferty często ją modyfikują, wkomponowując produkt lub usługę do praktyki życiowej. Tak zmodyfikowane nowe rozwiązania przyczyniają się do powstawania kolejnych innowacji o szerszym zasięgu (Bendyk 2010).

Przedstawiciele społeczeństwa mogą być zachęcani do podejmowania działań kreatywnych i dzielenia się swoimi pomysłami z producentami w ramach konkursów (które pozwalają wygrać różne nagrody) lub giełd innowacji (np. giełda Innocentives koncernu Procter and Gamble, projekt My Starbucks Idea, Bank Pomysłów Banku Zachodniego). Możliwe jest też tworzenie innowacji w ramach pracy społecznej niezależnych innowatorów współpracujących za pomocą komunikacji w internecie (zjawisko open source innovation). W ten sposób stworzono oprogramowanie open source (np. system operacyjny GNU/Linux) lub zasilane są zasoby wiedzy Wikipedii (Bendyk 2010). 
Budowanie gospodarki opartej na wiedzy wymaga uruchomienia mechanizmów o charakterze społecznym - zaufania społecznego, otwartości społeczeństwa na tworzenie i przyjmowanie oraz dyfuzji innowacji, a także systemu edukacyjnego umożliwiającego rozwój kreatywności. Koncepcja Quadruple Helix ujęła to, co wcześniej było często ignorowane - społeczny i kulturowy wymiar innowacji. Nowe rozwiązania powstają w społeczeństwie, a to wymaga tworzenia wśród ludzi i grup społecznych wielu relacji, więzi, norm i wartości, postaw i przekonań, a także ich ewolucji i powolnych przeobrażeń. Realizacja tych procesów prowadzących do zmian, w tym pod wpływem tworzonych nowych rozwiązań, następuje dzięki powstawaniu świadomości potrzeby zmian, pewnej kultury innowacyjnej, zaufania, społecznego klimatu przyzwolenia na wprowadzanie nowych rozwiązań w różnych sferach życia społecznego i wyznawania wspólnych wartości w społeczeństwie. Wszystko to tworzy tzw. kapitał społeczny. Wykorzystywany jest on do realizacji różnych innowacyjnych projektów w lokalnym i regionalnym środowisku (wspierających procesy rozwojowe), np. innowacji społecznych na rynku pracy, nowych rozwiązań w zakresie transportu publicznego, w ochronie zdrowia lub usługach publicznych (Wallin 2012).

Zjawisku innowacji przypisuje się także wymiar kulturowy. Innowacja może być rozumiana w szerokim ujęciu jako dzieło twórcze, rodzące się w głowach ludzi, którzy ją wprowadzają w czyn lub tworzą dzieło. Jeżeli znajdzie ono zainteresowanie i akceptację odbiorców, jest upowszechniane za pośrednictwem naśladownictwa, powielania w życiu społecznym. Tym samym przyczynia się do tworzenia kultury, dzieł sztuki, wynalazków, a w długim okresie cywilizacji, która z kolei buduje podstawy kolejnych działań twórczych i następnych innowacji (Labuda 2008). W tym ujęciu innowacja jest nowym zjawiskiem kulturowym, będącym jednocześnie efektem dotychczasowej kultury i nową jakością, która oddziałuje na zmianę dotychczasowego stanu pod wpływem różnych czynników endo- i egzogenicznych. Zaakceptowanie tych zmian przez społeczeństwo - pod wpływem dostrzeżenia głębszego sensu innowacji w wymiarze społecznym i kulturowym - umożliwia realizowanie innowacji w wymiarze technicznym (Bendyk 2010).

Oczywiście w modelu Quaruple Helix element społeczno-kulturowy, stanowiący czwartą helisę, wchodzi w interakcje nie tylko z przedsiębiorstwami, ale też z szeroko pojętą sferą systemu politycznego (państwa, rządu, regulacji, norm, bodźców i ograniczeń życia społeczno-gospodarczego, w tym przedsiębiorczości i innowacyjności) i uniwersytetami. Role pozostałych partnerów modelu opisano już w przypadku modelu potrójnej helisy. Każdy z uczestników procesów innowacyjnych czerpie z zasobów społeczeństwa (z wiedzy, kapitału ludzkiego, społecznego, kreatywności, środków finansowych i in.), jego organizacji pozarządowych, skłonności do angażowania się w przemiany prorozwojowe. $Z$ drugiej strony przedstawiciele społeczeństwa korzystają z tego, co oferują pozostali interesariusze. Reagując na ich ofertę i zakres oddziaływania, mogą ją modyfikować - nawet w przypadku działań administracji rządowej lub samorządowej. Tego rodzaju współpraca czterech grup partnerów umożliwia osiągnięcie największych korzyści w ramach procesów innowacyjnych w regionie i zwiększa jego potencjał rozwojowy. Quadruple Helix ujawnia jeszcze jeden ważny aspekt współpracy jej uczestników - budowanie demokracji i społeczeństwa demokratycznego (obywatelskiego), opartego na wolności, równości, partycypacji w zarządzaniu rozwojem regionalnym. Z drugiej strony tego rodzaju partnerstwa dla innowacji na poziomie regionu (Triple, Quadruple, Quintuple i N-Tuple Helix) są możliwe dzięki zasadom demokracji (Carayannis i Campbell 2014). 


\section{MODEL Quintuple Helix JAKO KONCEPCJA PARTNERSTWA REGIONALNEGO W WARUNKACH ZRÓWNOWAŻONEGO ROZWOJU}

W XXI w. ludzkość zaczyna dostrzegać, że rozwój cywilizacji napotyka wiele barier, którymi są wyczerpywanie zasobów naturalnych, ubożenie biosfery, zachwianie równowagi ekologicznej, czego przejawem staje się:

- globalne ocieplenie;

- klęski żywiołowe;

- klęski ekologiczne;

- brak możliwości zaspokojenia potrzeb egzystencjonalnych ludności w krajach słabo rozwiniętych z powodu niedostatecznej ilości zasobów: wody, ziemi na cele rolnicze, technologii niezbędnej do jej wykorzystania, odpowiedniej jakości powietrza;

- niemożność ocalenia terytorium kraju (np. zalewane są wyspy na Pacyfiku i Oceanie Indyjskim pod wpływem podnoszenia się poziomu mórz i oceanów).

Klęski głodu, nędza, konflikty militarne, skażenie środowiska naturalnego, katastrofy, brak odpowiednich warunków życia sprzyjają niekontrolowanej migracji części populacji. Te zjawiska stanowią potwierdzenie, że od pewnego czasu działalność gospodarcza człowieka w środowisku naturalnym na Ziemi prowadzi do narastania problemów cywilizacyjnych, które według Skowrońskiego (2006) powodują „[...] zachwianie społecznej i biologicznej struktury bytowania człowieka" (Skowroński 2006, s. 47). W tej sytuacji dalszy postęp cywilizacyjny jest możliwy na podstawie zasady zrównoważonego rozwoju - z zachowaniem praw przyrody i społeczno-gospodarczych aspiracji ludności naszej planety. Koncepcja ta zakłada, że mechanizmy rozwoju społecznego i gospodarczego muszą być zmienione - przewartościowane i ukierunkowane na świadome, odpowiedzialne gospodarowanie społeczeństwa w zgodzie z otoczeniem społecznym i przyrodniczym, z uwzględnieniem ograniczeń na tych obszarach.

W gospodarce opartej na wiedzy wyzwaniom, związanym z przekształceniem społeczeństwa i gospodarki w duchu zrównoważonego rozwoju, można sprostać dzięki współpracy wszystkich uczestników regionalnych systemów innowacyjnych, realizowanej w ramach modelu Quintuple Helix. Jego elementy tworzą (Carayannis i in. 2012):

- system szkolnictwa wyższego obejmujący uczelnie, a także publiczne i niepubliczne instytucje naukowo-badawcze;

- system ekonomiczny wraz z sektorem prywatnym (przedsiębiorstwa przemysłowe, usługowe);

- system polityczny i regulacyjny wraz działaniami państwa, rządu i samorządów;

- otoczenie społeczno-kulturowe tworzone przez świat mediów i społeczeństwo obywatelskie;

- środowisko naturalne i społeczeństwo żyjące w zgodzie z zasadami zrównoważonego rozwoju.

W tym przypadku społeczeństwo obywatelskie ukierunkowuje swoją produkcję, opartą na wiedzy i innowacjach, na tworzenie warunków do rozwoju zrównoważonego, co zapewni mu życie w zgodzie ze środowiskiem naturalnym. Model ten wskazuje, że możliwe jest osiągnięcie równowagi między gospodarką a społeczeństwem, środowiskiem naturalnym i demokracją. W tym celu wykorzystywane są zasoby społeczeństwa, przede wszystkim wiedza, know-how, kreatywność i innowacje. Sprzyja temu synergia partnerów (elementów modelu Quintuple Helix) (Carayannis $i$ in. 2012). W tym ujęciu rozwój zrównoważony w kontekście globalnym jest 
przenoszony na działania lokalne (regionalne), sprzyjające przedsiębiorczości, zwiększeniu innowacyjności i konkurencyjności podmiotów w regionie i samego regionu. Skupiają się one na poszukiwaniu praktycznych rozwiązań globalnych problemów tworzenia socjoekologicznych systemów gospodarczych na poziomie mezo (Baccarne i in. 2016; Sunina i Rivza 2016).

Model pięciokrotnej helisy (Quintuple Helix) stanowi rozwinięcie wcześniej opisanych modeli Triple i Quadruple Helix. Ujmuje jako element współpracy w regionalnym systemie innowacyjnym jeszcze jeden krąg (kolejną helisę), tzn. środowisko naturalne, w którym żyje społeczeństwo. Jak wskazują Carayannis i Campbell (2010), ta koncepcja tworzy „[...] ramy do transdyscyplinarnej i interdyscyplinarnej analizy rozwoju zrównoważonego i ekologii społecznej" (s. 62). Przenikanie się pięciu helis - współpracy środowiska naukowego i edukacyjnego, systemu gospodarczego z przedsiębiorstwami, systemu politycznego z administracją oraz społeczeństwa obywatelskiego z mediami i ze światem kultury oraz środowiska naturalnego może przyczyniać się do powstawania ekoinnowacji i ekoprzedsiębiorczości.

Poszczególne systemy tworzące model Quintuple Helix posiadają duży potencjał (kapitał: ludzki, informacyjny i społeczny, ekonomiczny oraz polityczny i prawny) do tworzenia nowych idei, prądów, zjawisk, regulacji, co w warunkach konieczności sprostania wyzwaniom „nowej” gospodarki i potrzeby zrównoważonego rozwoju jest podstawą tworzenia i przepływu wiedzy oraz wykorzystywania jej do powstawania i rozwijania koncepcji, tworzenia wynalazków, innowacji produktowych, usługowych, procesowych, marketingowych i organizacyjnych (Carayannis i in. 2012). W wyniku synergii wszystkich systemów i uczestników procesów innowacyjnych, realizowanych $w$ ramach modelu, tworzą się nowe szanse rozwoju dla regionu, lokalnych i regionalnych środowisk społeczno-gospodarczych dzięki produkcji opartej na wiedzy.

\section{PODSUMOWANIE}

Współczesne wyzwania gospodarki światowej - gospodarka oparta na wiedzy i zrównoważony rozwój skłaniają naukowców do prowadzenia intensywnych badań nad koncepcjami współpracy sieciowej (w ramach różnych modeli helisy) w regionalnych systemach innowacji i jej efektywności w zmieniającym się świecie. Z analizy zagranicznej literatury przedmiotu wynika, że w krajach wysokorozwiniętych prowadzone są badania teoretyczne i empiryczne w tym zakresie. Poza wkładem w rozwój wiedzy nad czynnikami i mechanizmami rozwoju regionalnego w modelach helisy dostarczają one ważnej wiedzy i praktycznych wskazówek przedsiębiorstwom, uczelniom, instytutom badawczym, reprezentantom jednostek samorządu terytorialnego, decydentom politycznych, przedstawicielom społeczeństwa obywatelskiego (m.in. organizacji pozarządowych) na temat rozwoju gospodarczego i regionalnego. Szczególnie istotne są koncepcje współpracy partnerów regionalnych systemów innowacyjnych w modelach Quadruple Helix i Quintuple Helix. Te dwa modele łączą uwarunkowania gospodarki opartej na wiedzy i potrzeby osiągania rozwoju zrównoważonego z miejscem, ze znaczeniem i z wkładem wszystkich interesariuszy regionalnych w procesy tworzenia innowacji wspomagających rozwiązywanie zarówno lokalnych, jak i globalnych problemów. 
Ewolucja tych koncepcji od modelu potrójnej helisy do modelu Quintuple Helix ukazuje, jak zmieniały się poglądy na temat współpracy na potrzeby rozwoju regionalnego na podstawie innowacji, jej partnerów i ich odpowiedzialności za ten proces oraz wykorzystywanych do rozwoju narzędzi. Od początku XXI w. coraz silniejszy wpływ na przebieg tych procesów ma społeczeństwo, jego kreatywność, wartości i postawy. Narastające problemy w środowisku naturalnym ujawniły konieczność uwzględniania w modelach współpracy także ekosystemów. Sprzężenie wszystkich elementów modelu Quintuple Helix wskazuje potencjał współpracy regionalnej, a wdrażane w wielu krajach jej zasady świadczą o skuteczności budowania w regionie środowiska innowacyjnego złożonego z pięciu helis - zachodzących na siebie systemów: nauki, gospodarki, polityki, społeczeństwa obywatelskiego i środowiska naturalnego.

W Polsce te najbardziej rozwinięte koncepcje współpracy w regionalnych systemach innowacji nie są jeszcze ani powszechnie znane, ani wdrażane w praktyce. Nadal trudności sprawia budowanie współpracy regionalnej opartej na modelu potrójnej helisy. W niewielkim stopniu rozważa się, w ujęciach teoretycznym i empirycznym, potencjał zawarty w modelu poczwórnej helisy. Nie postrzega się społeczeństwa obywatelskiego jako ważnego partnera w budowaniu gospodarki opartej na wiedzy, a samo społeczeństwo też nadal nie jest przygotowane do objęcia roli opisanej w modelu Quatruple Helix. Nieliczni polscy naukowcy w ujęciu teoretycznym próbują łączyć problematykę rozwoju regionalnego, innowacji, gospodarki opartej na wiedzy z problemami rozwoju zrównoważonego. Wskazuje to na duży potencjał badawczy w tym zakresie. Ujawnia również konieczność oddziaływania środowiska naukowego na wszystkie podsystemy modelu Qiuntuple Helix w celu stworzenia w naszym kraju odpowiednich sieci współpracy na rzecz rozwoju regionalnego opartego na innowacjach i rozwoju zrównoważonym.

\section{PIŚMIENNICTWO}

Afonso O. Monteiro S., Thompson M. 2010. A growth model for the Quadruple Helix. NIPE WP 12, http://www3.eeg.uminho.pt/economia/nipe/docs/2010/NIPE_WP_12_2010.pdf, dostęp: 15.12.2017.

Baccarne B., Logghe S., Schuurman D., De Marez L. 2016. Governing Quintuple Helix innovation. Urban living labs and socio-ecological entrepreneurship. Technol. Innovat. Manag. Rev. 6(3), 22-30.

Barca F., McCann P., Rodriguez-Pose A. 2012. The case for regional development intervention: place-based versus place-neutral approaches. J. Reg. Sci. 52(1), 134-152.

Bendyk E. 2010. Kulturowe i społeczne uwarunkowania innowacyjności, w: Raport „Innowacyjność” 2010. Red. P. Zadura-Lichota. Warszawa, PARP, 71-89.

Bojar M., Machnik-Słomka J. 2014. Model potrójnej i poczwórnej helisy w budowaniu współpracy sieciowej dla rozwoju innowacyjnych projektów regionalnych. Zesz. Nauk. PŚı., Ser. Organizacja i Zarządzanie 76, 99-111.

Camagni R., Capello R. 2013. Regional innovation patterns and the EU regional policy reform: toward smart innovation policy. Growth Chan. 44(2), 355-389.

Carayannis E.G., Campbell D.F.J. 2009. 'Mode 3' and 'Quadruple Helix': Toward a 21st century fractal innovation ecosystem. Inter. J. Technol. Manag. 46(3/4), 201-234.

Carayannis E.G., Campbell D.F.J. 2010. Triple Helix, Quadruple Helix and Quintuple Helix and how do knowledge, innovation and the environment relate to each other? A proposed framework for a transdisciplinary analysis of sustainable development and social ecology. Inter. J. Soc. Ecol. Sust. Develop. 1(1), 41-69, http: //www.igi-global.com/bookstore/article.aspx?titleid=41959, dostęp: 12.12.2017. 
Carayannis E.G., Barth T.D., Campbell D.F. 2012. The Quintuple Helix innovation model: global warming as a challenge and driver for innovation. J. Innov. Entrepren. 1(1), 1-12, http: www.innovation-entrepreneurship.com/content/1/1/2, dostęp: 28.11.2017.

Carayannis E. G., Campbell D.F.J. 2014. Developed democracies versus emerging autocracies: arts, democracy, and innovation in Quadruple Helix innovation system. J. Innov. Entrepren. 3(1), 12, http: www.innovation-entrepreneurship.com/content/3/1/12, dostęp: 12.12.2017.

Cooke P.U., Uranga M.G., Etxebarria G. 1992. Regional systems of innovation: an evolutionary perspective. Environ. Plan. 30, 1563-1584.

Dolińska M. 2010. Innowacje w gospodarce opartej na wiedzy. Warszawa, PWE, 13-16.

Doloreux D., Parto S. 2005. Regional innovation system: Current discourse and unresolved issues. Technol. Soc. 27, 133-153.

Etzkowitz H., Leyesdorff L. 1995. The Triple Helix: University-Industry-Government Relations: A Laboratory for Knowledge-Based Economic Development. EASST Rev. 14, 14-19.

Harari Y.N. 2018. Homo Deus. Krótka historia jutra. Warszawa, Wydaw. Literackie 2018.

Labuda G. 2008. Rozważania nad teorią i historią cywilizacji. Poznań, Wydaw. Poznańskie, 229.

Leyesdorff L. 2012. The Triple Helix, Quadruple Helix..., and an N-tuple of Helices: Explanatory models for analyzing the knowledge-based economy? J. Knowledge Econ. 3(1), 25-35.

Markowski T. 2000. Regionalne systemy innowacji w aspekcie strategii rozwoju regionalnego Polski 2000-2006. Biul. KPZK PAN, 191, 142.

Mitek A., Miciuła I. 2012. Współczesne determinanty rozwoju przedsiębiorstw prywatnych. Stud. Pr. Wydz. Nauk Ekon. Zarz. USzczec. 28, 60.

Nowicki M. 2018. Zagadka nieśmiertelności. Newsweek 14, 24-27.

Regional innovation system. The roles of governances in a globalized world. 1988. Eds. H.-J. Braczyk, P. Cooke, M. Heidenreich. London, UCL Press.

Skowroński A. 2006. Zrównoważony rozwój perspektywą dalszego postępu cywilizacyjnego. Probl. Ekorozwoju 1(2), 47-57.

Sojusz głów. Rozmowa z prof. Marcinem Pałysem, rektorem Uniwersytetu Warszawskiego, o najnowszej reformie nauki i szkolnictwa wyższego. 2018. Polityka 15(3156), 66-67.

Spark. Scale. Sustain. Innovation for the Sustainable Goals. 2017. New York, UNDP, http://www.undp.org/content/undp/en/home/librarypage/development-impact/spark-_-scale-_-sustain--2016-year-in-review.html, dostęp: 21.03.2018.

Stanienda J. 2011. Clusters in the system of region innovation. The Małopolska School of Economics in Tarnów Research Papers Collection 19, 155-165.

Sunina L., Rivza B. 2016. The Quintuple Helix Model: way of regional development centres in Latvia to smart public administration. Res. Rural Develop. 2, 135-142.

Wallin S. 2010. The co-evolvement in local development - from the triple to the quadruple helix model, in: Proceedings from 8th Triple Helix Conference, Madrid October 20-22, 2010, http://leydesdorff.net/th8/TRIPLE\%20HELIX\%20-0VIII\%20CONFERENCE/PROCEEDINGS/0110_ Wallin_Sirkku_O-104/triple\%20helix\%20Wallin\%20final.pdf, dostęp: 11.12.2017.

Streszczenie. Tworzenie innowacji regionalnych $w$ gospodarce opartej na wiedzy wymaga współpracy różnych partnerów - instytucji naukowych i badawczych, przedsiębiorstw, jednostek samorządu terytorialnego, instytucji otoczenia biznesu, organizacji pozarządowych, społeczeństwa, mediów. W ostatnich latach relacje między nimi są coraz ważniejsze w kontekście tworzenia i wdrażania innowacji na potrzeby zrównoważonego rozwoju w mikro-, mezoi makroskali. Teoretyczne ramy takiej współpracy formułują modele poczwórnej i pięciokrotnej helisy (quadruple i quintuple helix). Stanowią one rozwinięcie koncepcji Etzkowitza i Leydesdorffa potrójnej helisy (uniwersytet - przemysł - rząd) o sferę mediów i społeczeństwa obywatelskiego (quadruple helix), a następnie o kontekst ekologiczny - społeczeństwa XXI w. żyjącego 
w środowisku naturalnym, które musi uwzględniać zasady zrównoważonego rozwoju (quintuple helix). W pracy przeprowadzono analizę zagranicznej i krajowej literatury przedmiotu. Praca sygnalizuje potrzebę nowego spojrzenia regionalnych interesariuszy w Polsce na mechanizm i przebieg procesów innowacyjnych zmierzających do tworzenia rozwiązań współczesnych problemów gospodarki światowej. Koncepcje Quadruple i Quintuple Helix w Polsce nie są jeszcze ani powszechnie znane, ani wdrażane. Niezbędne jest oddziaływanie środowiska naukowego na tworzenie takich sieci współpracy w regionie na potrzeby tworzenia innowacji w warunkach zrównoważonego rozwoju. 
